UDC 783.6

\author{
Tatarnikova Anzhelika, ${ }^{\text {a }}$ \\ Candidate of Pedagogical sciences, \\ doctoral candidate, lecturer at the Department \\ of Theoretical and applied Cultural studies \\ of the Odessa National Musical Academy \\ A.V. Nezhdanova \\ angelikatatarnikova75@gmail.com \\ ORCID: 0000-0002-6310-827
}

\title{
INTONATIONAL-SEMANTIC ASPECTS OF THE IMPLEMENTATION OF THE IMAGES OF GLORIFICATION-PRAISE IN THE GERMAN PROTESTANT MUSICAL AND HISTORICAL TRADITION
}

The purpose of the article is to identify the intonational-semantic specifics of the implementation of praiseglorification images in the German Protestant liturgical and singing and creative musical and historical traditions. The methodology of the work on the intonation concept of music from the perspective of stylistic, etymological analysis, as well as on interdisciplinary and historical-cultural approaches that allow revealing the spiritual-semantic and genreintonational features of the interpretation of the designated figurative sphere of German spiritual culture and music. The scientific novelty of the article is determined by the fact that it first generalized the poetic-intonational specificity of depicting praise-glorification images in line with the religious attitudes of Lutheranism ("theology of glory," "theology of the cross"), as well as the work of German composers of the 18th-19th centuries. Conclusions. Glorious-glorious themes occupy one of the essential places in European Christian culture, in particular, in German Protestant, defining the vectors of its spiritual and semantic orientation. Genetically dating back to the Byzantine Eastern Christian tradition and to the spiritual precepts of the early Middle Ages of the Undivided Church, the confessional tradition in translating the images of praise and glorification («Te Deum» and «Gloria» in their German version) was formed at the intersection of the Protestant doctrines of «theology of glory» and «theology of the cross». The intonational-semantic specificity of Lutheran chorales associated with the designated figurative-semantic sphere demonstrates contact with a variety of confessional Christian traditions - Catholic (appeal to the intonational material of Gregorianic), Eastern Christian (appeal to the spiritual texts of the early Middle Ages), thereby revealing the specificity of spiritual and creative German composers of the 18th-19th centuries.

Key words: Protestant choral, "Te Deum," "Gloria," Reformation, German culture, "theology of glory," "theology of the cross."

Татарнікова Анжеліка Анатолї̈вна, кандидат педагогічних наук, докторант, викладач кафедри теоретичної та прикладної культурології Одеської національної музичної академії ім. А. В. Нежданової

Інтонаційно-семантичні аспекти відтворення образів хваління-славослів'я у німецькій протестантській музично-історичній традиції

Мета статті - виявлення інтонаційно-смислової специфіки відтворення образів хваління-славослів'я в німецькій протестантській богослужбо-співацькій та творчій музично-історичній традиції. Методологічна основа роботи спирається на інтонаційну концепцію музики в ракурсі стилістичного, етимологічного аналізу, а також на міждисциплінарний та історико-культурологічний підходи, що дозволяють виявити духовносемантичні та жанрово-інтонаційні особливості трактування позначеної образної сфери німецької духовної культури та музики. Наукова новизна статті визначена тим, що в ній вперше узагальнено поетико-інтонаційну специфіку відтворення образів хваління-славослів'я у річищі релігійних настанов лютеранства («теологія слави», «теологія хреста»), а також творчості німецьких композиторів XVIII-XIX століть. Висновки. Славословно-глоріозна тематика займає одне з суттєвих місць у європейській християнській культурі, зокрема, у німецькій протестантській, визначаючи вектори іiі духовно-смислової спрямованості. Генетично висхідна до візантійської східнохристиянської традиції та до духовних настанов раннього Середньовіччя епохи Неподіленої церкви, названа конфесійна традиція у відтворенні образів хваління-славослів’я («Те Deum» та «Gloria» в їх німецькому варіанті) формувалася на перетині протестантських доктрин «теології слави» та «теології хреста». Інтонаційно-семантична специфіка лютеранських хоралів, пов'язаних 3 позначеною образно-смисловою сферою, демонструє контактність з різноманітними конфесійними християнськими традиціями - католицькою (звертання до інтонаційного матеріалу григоріаніки), східнохристиянською (апелювання до духовних текстів раннього Середньовіччя), виявляючи тим самим духовно-стильову специфіку творчості німецьких композиторів XVIII-XIX століть.

Ключові слова: протестантський хорал, «Те Deum», «Gloria», Реформація, німецька культура, «теологія слави», «теологія хреста».

CTatarnikova A., 2019 
Татарникова Анжелика Анатольевна, кандидат педагогических наук, докторант, преподаватель кафедры теоретической и прикладной культурологии Одесской начиональной музыкальной академии им. А. В. Неждановой.

Интонационно-семантические аспекты претворения образов хваления-славословия в немецкой протестантской музыкально-исторической традиции.

Цель статьи - выявление интонационно-смысловой специфики претворения образов хваления-славословия в немецкой протестантской богослужебно-певческой и творческой музыкально-исторической традиции. Методологическая основа работы опирается на интонационную концепцию музыки в ракурсе стилистического, этимологического анализа, а также на междисциплинарный и историко-культурологический подходы, позволяющие выявить духовно-семантические и жанрово-интонационные особенности трактовки обозначенной образной сферы немецкой духовной культуры и музыки. Научная новизна статьи определена тем, что в ней впервые обобщена поэтико-интонацийнная специфика запечатления образов хваления-славословия в русле религиозных установок лютеранства («теология славы», «теология креста»), а также творчества немецких композиторов XVIII-XIX веков. Выводы. Славословно-глориозная тематика занимает одно из существенных мест в европейской христианской культуре, в частности, в немецкой протестантской, определяя векторы ее духовно-смысловой направленности. Генетически восходящая к византийской восточнохристианской традиции и к духовным установкам раннего Средневековья эпохи Неразделенной церкви, названная конфессионная традиция в претворении образов хваленияславословия («Te Deum» и «Gloria» в их немецком варианте) формировалась на пересечении протестантских доктрин «теологии славы и «теологии креста». Интонацинно-семантическая специфика лютеранских хоралов, связанных с обозначенной образно-смысловой сферой, демонструет контактность с разнообразными конфессионными христианскими традициями - католической (обращение к интонационному материалу григорианики), восточнохристианской (апеллирование к духовным текстам раннего Средневековья), выявляя тем самым духовно-стилевую специфику творчества немецких композиторов XVIII-XIX столетий.

Ключевые слова: протестантский хорал, «Те Deum», «Gloria», Реформация, немецкая культура, «теология славы», «теология креста».

Relevance. One of the oldest functions of music related to its spiritual mission is the praise, praise to God, gathered in the genre form of the anthem, the hymn. The latter are important at the Christian spiritual-liturgical and cultural-historical tradition at all its variety of confessional manifestations. Praise-hymn to the Creator as the most important sense-forming vector of spiritual existence of man is symbolically correlative with the ancient cult musical genres Gloria, glorification, as well as Te Deum, which entered in various forms both in the Orthodox liturgical tradition and in the Christian rites of the Western European world, in particular, in the German Protestant. The named genre sphere is widely represented in the works of German authors of the XVII-XIX centuries, represents the spiritual and intonation "sound" of Christian culture of Europe, including the legacy of I. S. Bach, his contemporaries and followers, whose works are widely claimed at the performing practice of our time.

An analysis of research and publications. The named genre sphere is widely represented in the works of German authors of the XVII-XIX centuries, represents the spiritual and intonation "sound" of Christian culture of Europe, including the legacy of I. S. Bach, his contemporaries and followers, whose works are widely in demand in the performing practice of our time. Among the latter, the significant place belongs to the works of A. Schweitzer [18], M. Druskin, I. Druskin, B. Yavorsky, didn't focus only at work of I. S. Bach, but also on the spiritual teachings of his creative heritage, directly related to the Protestant "image of the world" and its culture. Their generalizations are supplemented by studies of recent decades, directly focused on the identification of genre-style and spiritual-homiletic specifics of the composer's spiritual cantatas [2], as well as their integration into the Lutheran cult practice [14]. We also underline the thesis and related publications of G. Dombrausken [6; $7 ; 8$ ], which reveal the axiological nature and specificity of religious symbols of the German Protestant chorale. However, mentioned authors often prefer generalized consideration of the designated problems, while the multifaceted figurative-semantic and rhetorical specificity of the Protestant chorale, in particular, its gloriouslypraised component, directly related to Lutheran theology, yet remains out of the field of view of modern researchers. The article's purpose - identification of intonation and semantic specificity of the reconstruction of images of glorify-praise in the German Protestant liturgical and singing and creative musical and historical tradition. The work's methodology the work is based on the intonation concept of music from the perspective of stylistic, etymological analysis, as well as interdisciplinary, historical and cultural approaches to reveal the spiritual,semantic and genre-intonation features of the interpretation of the designated figurative sphere of German spiritual music and culture.

The scientific novelty of the article is determined by the fact that for the first time it summarizes the poeticintonational specificity of the reproduction of images of glorify-praise in line with the religious beliefs of Lutheranism ("theology of glory", "theology of the cross"), as well as the work of German composers of the XVIII-XIX centuries.

Presenting the main material. Various textual basis of the Christian glorify-prased items presented in Gloria, Te Deum, and the like, focused on such key concepts of the Christian faith as "glory", "praise", "glorify", 
"appreciation", "the exaltation," "worship". Each of them, having an independent meaning, at the same time is closely connected with each other by a single meaning, spiritualizes the life path of a person. In addition, all of them form the semantic basis of some very important sections of Christian worship, being represented by independent texts and liturgical singing.

It should also be noted that their significance in Church practice is determined not only by the new Testament sources, but also by the key role of the image of God's Glory in Christianity as a whole. In this case, it can be considered both at the level of the theological category and at the level of the spiritual and moral principle, which is the link between the Divine and the human worlds. Showing the specifics of this relationship, the blessed Theodore says "that "the Lord God does not need praising", but the awe and admiration of the intelligent creations of God for the greatness of his works can not be expressed in the offerings to God of heartfelt praise and gratitude." Reflecting on the essence and significance of God's glory in human spiritual existence, Archpriest Livery (Voronov) points out that "...the glorification of God by life and deeds is the main purpose of man as a participant in the love of God" [11].

It should also be noted that the praise to God, the ascension of praise to Him throughout Christian history is associated with "chanting", because "praise is born from admiration and surprise in the Face of God in the soul, which was revealed and engulfed in delight. It can be expressed in appeals, exclamations, in joyful praise <...> Since praise should be understandable to the people, it easily becomes a song, a hymn, often accompanied by music and even dance in its development " [17]. Thus, the said reveals the initial vocal and singing nature of the sphere of glorification in the Christian tradition, remains relevant for many centuries up to the present time both in the Church-everyday version and in the creative and compositional one.

The capacity and all-embracing nature of the glorification in all the variety of its manifestations in Christian theology and ritual practice determines the multiplicity of its meanings. "The Glory of God" means, first of all, God himself or "the form of the full presence of the deity." It is in this sense that the Apostle Paul uses this concept when he says: "And we have seen his glory as the only begotten of the Father" (Jn. 1: 14). For John the theologian essential in this case is the fact that the Glory of the Lord is visible and it can be compared with the radiation of the sun and the moon, but it surpasses them (Rev. 21:23). This semantic aspect is correlated with the second meaning of the "Glory of the Lord", focused on the embodiment of the divine absolute greatness, which is manifested in the creations of God. It should also be noted that the indicated quality will be the subject of musical and rhetorical reproduction in the typology of Gloria, Te Deum and those close to them both at the level of the composite liturgical cycle and at the level of the independent compositional whole. At the same time, the image of "Divine greatness" is associated with the spatio-dynamic, "universal" quality of its presentation, focused on bright dynamics, the presence of a wide sound range and etc.

Finally, another meaning of the term "Glory of God" is related to the reflection of God's greatness in the works and objects of His Creation and Providence. "The knowledge of divine glory is possible both through the contemplation of the world created by God and through the actions of divine grace. Contemplating the world, a person experiences the infinite greatness of the Creator, reduces his mind to the root cause of the universe, which exceeds everything that exists...> The inner contemplation of the glory of God leads man to likening himself to his Creator, to finding the Kingdom of God in his soul, to spiritual transformation..."[16].

The designated aspects of the understanding of "glory-praise" received various incarnations in the multiconfessional spectrum of Christian culture, including the German Protestant tradition, formed on the basis of the events of the reformation, which entered the world history, on the one hand, as a "revolution of spirit", significantly enriched the Western European image of the world of Modern times, on the other - marked the formation of the German religious spirit on the way to Christian freedom. However, the teachings of M. Luther and his Church reforms can be seen as a Grand attempt to return to the ideas of Christianity of Apostolic times and traditions of the Undivided Church, which was expressed not only in the opposition of the reformed Church to other denominations, but also in the intersection of their spiritual and religious attitudes.

The latter is obvious in particular in the fact that the universal symbols of faith were recognized by Lutherans from the first years of the reformation, as N. Luther once wrote: "Three symbols or confessions of faith in the Church were adopted unanimously, namely, the Apostolic, Athanasian symbols, Te Deum laudamus" [1, 102]. Remembering the latter, the German reformer had in mind not only a specific liturgical text and its Churchsinging component, but also the above-mentioned religious and theological quality. The generalization of the latter made it possible to formulate five basic theses of the Protestant creed, which were summarized in the socalled "5 Sola": "Sola scriptura ("one Scripture"), Sola gratia ("Only one grace"), Sola fide ("Only one faith"), Sola Christus ("Only Christ"), Soli Deo Gloria ("Only glory to God"). The last principle, according to S. Sannikov, "expresses the eschatological anticipation and expectation, which starts on the ground in a continuous doxology, praising God..."[15, 85, 90]. 
The emphasis of the vector orientation of the spiritual life of man on transformation through glory-praise formed the basis for the formation of the concepts of "theology of glory" and "theology of the cross" within Protestantism [see more about it: 12, 369, 403], which determined the most essential aspects of his worldview. The first of them was the dominant religious idea of Calvinism, the essence of which M. Weber defined as follows: "the World exists in order and only to serve the self-glorification of God; the Christian chosen one exists for and only in order to carry out in his daily life the commandments for the glory of the most high <...> Social activities calvinst in the world - activities "in majorem gloriam Dei"" [3, 33-34]. The concept of "theology of the cross" is dominant in the teachings of N. Luther, who formulated it at the Heidelberg dispute in 1518. According to the German reformer, "now no one can truly know God in His glory and greatness, until he knows It in the humiliation and disgrace of the cross" [CIT. by: 4, 24].

The ideas that demonstrate the diversity of religious positions of the basic directions of Protestantism, on the one hand, reveal the divergence of the teachings of the leaders of the reformation. On the other hand, "antinomy "of"glory" and "cross" is very conditional, because, according to G. Florovsky, "the cross itself is a sign of Glory" $[13,463]$. Such an understanding of Evangelical images-symbols and their spiritual meaning (without the formulation of the relevant theological concepts) is indicative not only for Protestantism itself, but also for other confessions - Orthodoxy, Catholicism. The understanding and perception of Christianity in the context of the domination of the idea of God's glory is typical for the Eastern Christian tradition, in particular, for the Byzantine, theological thought and spiritual culture which formed the basis for the culture of the whole of Europe, including the German reformation. According to G. Kolpakova, the image of the Savior in the system of images of harmony and glory of the Heavenly Kingdom, represented in the art of Byzantine iconography, "very rarely appears in the type of kenosis - humiliated by suffering, which is characteristic of Western painting. In Byzantium it is almost always the image of Christ in glory - in the type of Pantocrator. The incarnation of the second person of the Trinity in itself signified the reconciliation of God with man, was an image of the glorified, not the fallen creation. The theme of suffering of the Savior <...> always turns the subject of the Supreme triumph" [10, 22].

The ideas laid down in the biblical sources, at the level of complementarity, actually form the basis of Protestant theology, combining its most famous representatives. The differences in their positions, conditioned by the spiritual and historical realities of their time, nevertheless do not exclude the understanding of the unity and conditionality of the "theology of glory" and "theology of the cross".

This applies in the Protestant (including Lutheran) religion not only to the theological sphere of human existence, but also to his professional activity. The spiritual understanding of the latter is summarized by the term Beruf, which in this confessional tradition is interpreted as "God-given purpose". At the same time, any earthly practical activity "is considered as what is done for the Glory of God. Perhaps it was this dimension that became the main point of Protestant ethics, which formed the spirit of capitalism. Thus, ordinary earthly professions were sanctified and became work for God" $[15,90]$. Such an understanding of the meaning of life and creative work is also indicative of the activities of Baroque masters, in particular, for I. S. Bach, who repeatedly wrote in his manuscripts or in the form of a monogram, or the full text of the Protestant imperative mentioned above Soli Deo Gloria (SDG). In addition, according to his definition, "the ultimate and final goal of General bass, like all music, is to serve the Glory of God and the refreshment of the spirit. Where this is not taken into account, there is no real music, but there is diabolical chatter and noise" [18, 121].

The indicated qualities of the interpretation of the basic teachings of the Christian doctrine concerning the glory of God and its components, which have shown their novelty and, at the same time, continuity, have been recreated in the intonation-semantic specificity of the corresponding sphere of the German Protestant chorale. The latter " forms a metatextual phenomenon, acting as a kind of Bank of meanings and meanings, as well as melodic and poetic material. In addition to the applied function of accompanying the service, supplementing the sermon, Protestant hymns contribute to the translation and transmission of religious experience", making together one of the most important "metaphysical values" of religious, cultural and historical heritage of Germany [6, 236-237].

Paying considerable attention to the musical component of the service, M. Luther demanded that there be a close connection between it and biblical reading. K. Rudik, based on numerous materials on the history of the Lutheran Church, testifies that "Luther encouraged the diversity of genres and forms of music presentation in the Church, which was reflected, in particular, in the encouragement of one-voice Gregorian chants in Latin, in the creation of new Psalms and hymns in German, the introduction of polyphonic works written both in Latin and German texts" [14, 20].

This is also correlative with the Protestant chorales, which are tangent to the sphere of praise-praise. One of the most important places in it is the German analogue of the anthem "Te Deum" ("Herr Gott dich loben wir"), which exists in the Lutheran practice in various versions. One of them is represented by Gregorian chant, which is voiced by the German text (Latin translation by M. Luther, carried out in 1529) [19, № 137]. It is to him that I. S. 
Bach addresses in his cantata No. 16, created directly for the new year holidays and the circumcision of the Lord. This chorale is reproduced in the first part of the cycle in the upper voice of the choral array (according to Protestant tradition) against the background of polyphonically stated anniversaries in the parties of other (lower) voices, representing in the aggregate the image of glory-praise-gratitude addressed to God in the context of the beginning of the new year and the next stage of spiritual life-the transformation of man. A similar method is reproduced by Bach in cantata No. 190 (1724 Leipzig), which was also created directly before the new year Christian holidays. In this composition, the Latin Te Deum with the German text in the monodiale version, in large trivalities (by analogy with the early Christian tradition) is the culmination of the first part of the cycle. It is significant that the musical material of this cantata I. S. Bach later used in the work dedicated to the anniversary of the "Augsburg confession" (cantata № 190A), which now serves as a religious document and theological norms for Lutherans. Thus, the composer's appeal in these works to the chant of the early Christian Church and its German-Lutheran "reading" in conjunction with the symbolism of Christian holidays and significant events in the spiritual and religious life of Germany is a very rich spiritual and semantic background of this praise in the context of national cultural and spiritual and historical tradition.

At the same time, within the framework of the Lutheran liturgical singing practice, purely German everyday version of Te Deum is also known [see: 19, No. 115], known since the middle of the XVI century. In addition to its basic spiritual and semantic praiseworthy function ("You, God, praise"), it performs the role of a certain melodic "like" for a number of other Lutheran chorales, each of which, nevertheless, also covers various semantic aspects of the multifaceted theme of God's glory and greatness.

So mentioned German Te Deum in the Lutheran liturgical practice is also associated with the veneration of the image of the Archangel Michael, who is considered the spiritual patron of Germany. A. DobiashRozhdestvenskaya, exploring the cult of St. Michael in the Latin middle Ages, in particular, and in the German lands, States that "in the Jewish legend, the Archangel Michael acts as the leader and fighter for the people of Israel; in Christian - as the winner of the "ancient serpent" (Satan in the Apocrypha) at the beginning of time, and the Antichrist - at the end of the universe. In his name and meaning - "Who, as God" - he is in the late Jewish creed is represented as an active double of the deity: "And where you see Michael, there understand the presence of the deity" " [5, III]. At all further stages of the development of Christianity, he always acts as a champion of the glory of God, as a defender of the human race and the Church. Interestingly, the attributes of the Archangel Michael - sword and shield - in the German Protestant imagination also accompany in the symbolic perception of God, as It represents M. Luther in the famous chorale "Ein feste Burg": "our Lord sword, stronghold and shield and strong stronghold." The great German reformer himself as a militant figure in the minds of many of his compatriots was also symbolically associated with the majestic figure of the Archangel Michael.

Let's note that I. S. Bach wrote at least four cantatas (№№ 130, 19, 50, 149), dedicated to the festive service in honor of the Archangel Michael. The above-mentioned tendency of rapprochement of personality with God can be seen, for example, in cantata № 130, where in the first part the image of glory-praise in honor of the Archangel voiced by the text and chant of the German Te Deum, which is presented in the textured version, similar to cantata № 16 (see above).

Returning to other choral varieties of glorify-praise, we note that the melody of the Lutheran Te Deum is used both in the "voicing" of the 134 Psalm-praise "Praise the name of the Lord" [19, № 196], and in the melodious version of the 103 Psalm telling about the creation of the world as a manifestation of divine glory [19, № 188]. Appropriate this chant is in the service of the Holy Trinity [19, № 112]. In addition, one of its variants is also used in the literary practice related to the anniversary of the reformation [19, № 117]. The text of this song is the semantic basis for the chorale "Fur Volk und Vaterland" [19, № 393], coming from the grateful chorale "Nun danket alle Gott" [19, № 228]. The semantic-intonation principles of the named samples of Lutheran liturgical use fed the creativity of I. S. Bach (cantata No. 190), and also formed the basis for the musical language of the "triumphal song" by I. Brahms, which combined both the historical realities of Germany in the second half of the XIX century (the creation of the German Empire) and the memory of its spiritual and religious national heritage.

In the list of prased-glorious Lutheran everyday life the essential place belongs also to the German analog Gregorian Gloria that in the German translation is sounded as "Allein Gott in der höh'ei Ehr" [19, No. 131]. The prototype of the hymn was one of the parts of the ordinary of the mass, which since the XII century. it was an obligatory part of the Liturgy (lat. "Gloria in excelsis Deo et in terra pax hominibus bonae voluntatis"). Lutheran chorale-analogue was created in 1522 by a close associate of M. Luther, a graduate of the University of Leipzig, Cantor, composer and poet Nikolaus Decius. His numerous hymns have been recognized by Protestant communities.

G. Dombrauskene, analyzing in their article, "semantic syncretism" and the intonation the specifics called the Protestant hymn, which was included in the so-called "German mass" called "Das Gloria in Excelsis", comes 
to the conclusion that he is a mirror image of its Latin source. According to the researcher, the method used in her article "the method of mirror comparison of the melodic contour of the anthem phrase and its mirror version seems appropriate, as it allows to construct an integral graphic image". The diagram given in the study "demonstrates the result of the experience - mirror conjugacy (Rus. "looping") of the matched lines forms one of the most common Christian symbols - "fish". This symbol is one of the oldest acronyms of the name of Jesus Christ " [8, 243].

Anthem of Nikolaus Decius "Allein Gott in der Höh'sei Ehr" has become one of the most famous Protestant hymns, to which was referred G. L. Hassler, M. praetorius, H. schütz, F. Zachau, G. Telemann, Mendelssohn and others. Th. S. Bach repeatedly refers to the Latin and German versions of "Gloria" in his spiritual cantatas, which we find in № 50. 191 cantata, created on the feast of the Nativity of Christ, includes Latin text and musical material from "Gloria" high mass h-moll. The absence of choral quotations here is compensated by a wide Arsenal of musical and rhetorical means that in German Baroque music were associated with the theme of praise (D-dur, dotted lines, the presence of numerous quartz turns, the dominant role of timbre of brass instruments, etc.). Particular attention is drawn to the use in the initial motif of the rhetorical figure "arch", which "... it was used in the effect of praise; the firmness of the architectural form of the arch symbolizes faith in salvation " [9, 108].

Conclusion. Thus, the glorified-praise theme occupies one of the essential places in the European Christian culture, in particular, in the German Protestant, defining vectors of its spiritual and semantic orientation. Genetically going back to the Byzantine Eastern Christian tradition and in the spiritual teachings of the early Middle Ages of the era of the Undivided Church, called confessional tradition in the reconstruction of images of praise-praise ("Te Deum" and "Gloria" in their German version) was formed at the intersection of Protestant doctrines "theology of glory" and "theology of the cross." Intonation-semantic specificity of Lutheran chorales associated with the designated figurative and semantic sphere, demonstrates contact with various confessional Christian traditions - Catholic (appeal to the intonation material Grigorianic culture), East Christian (appeal to the spiritual texts of the early Middle Ages), thus showing the spiritual and stylistic specificity of the work of German composers of the XVIII-XIX centuries.

\section{Jimepamypa}

1. Архимандрит Августин (Никитин). Аугсбургское вероисповедание - вероучительная книга лютеранства // Христианское чтение. 2011. № 2 (37). С. 54-138.

2. Берденникова Е. М. Гомилетические традиции духовных кантат И. С. Баха. К.: Музична Україна, 2008. $204 \mathrm{c}$.

3. Вебер М. Избранное: Протестантская этика и дух капитализма. М.: РОССПЭН, 2006. 656 с.

4. Волжин С. В. Теология креста (theologia crucis) Мартина Лютера и история спасения // Реформация и протестантизм в мировой истории. К 500-летию Реформации Мартина Лютера: сборник тезисов и докладов. СПб.: Санкт-Петербургское Общество Мартина Лютера, 2017. С. 19-25.

5. Добиаш-Рождественская О. А. Культ св. Михаила в латинском Средневековье. V-XIII века. Петроград: Экономическая Типо-Литография, 1917. 395 + VI с.

6. Домбраускене Г. Н. Аксиологическая природа и специфика религиозной символики немецкого протестантского хорала // Вестник МГУКИ. 2012. № 4 (48). С. 235-240.

7. Домбраускене Г. Н. Метатекст протестантского хорала: семиотический континуум в музыкальной культуре Запада и Востока: автореф. дисс. ...доктора искусствоведения: 17.00.09 / Саратовский Морской государственный университет имени адмирала Г. И. Невельского. Саратов, 2014. 53 с.

8. Домбраускене Г. Н. Семантический синкретизм гимна «Allein Gott in der Höh'sei Ehr» («Песнь ангелов») и принцип декорирования инициала средствами музыкального языка // Проблемы музыкальной науки. 2013. № 2 (13). С. 241-245.

9. Казарян Г. Семантическая продуктивность иконических символов в музыкальных контекстах (И. С. Бах, Д. Д. Шостакович) // Критика и семиотика. 2012. Вып. 16. С. 106-117.

10. Колпакова Г.С. Искусство Византии. Ранний и средний периоды. СПб.: Издательская Группа «Азбука-классика», 2010. 528 с.

11. Ливерий (Воронов), протоиерей. Догматическое богословие. URL: https://azbuka.ru/otechnik/LiverijVoronov/ (дата звернення: 12.11. 2018 р.).

12. Мак-Ким Дональд К. Вестминстерский словарь теологических терминов: Пер. с англ. М.: Республика, 2004. $503 \mathrm{c}$.

13. Протоиерей Г. Флоровский. Этос Православной Церкви // Православие: pro et contra. СПб.: Издательство Русского Христианского гуманитарного университета, 2001. С. 451-466.

14. Рудик Е. А. Духовные кантаты И. С. Баха в контексте лютеранского богослужения: дисс. ... канд. искусствоведения: 17.00.02 / Саратовская государственная консерватория им. Л. В. Собинова. Саратов, 2018. $232 \mathrm{c}$. 
15. Санніков C. 5 Sola Реформації. Богословські принципи гетерогенного протестантизму // Схід. 2017. № 3 (149). Травень-червень. С. 83-92.

16. Слава Божия. URL: https://azbuka.ru/slava-bozhiya (дата звернення: 12.11. 2018 р.).

17. Хвала. URL: http://yakov.works/spravki/4_faith_ukaz/22_h_vera/hvala.htm (дата звернення: 08.11. 2018 p.).

18. Швейцер А. Иоганн Себастьян Бах. М.: Музыка, 1965. 728 с.

19. Evangelisches Kirchengesangbuch. Ausgabe fur die Vereinigte protestanisch Christlishe Kirche der Pfalz.

\section{References}

1. Arkhimandrit Avgustin (Nikitin) (2011). The Augsburg Confession is a doctrinal book of Lutheranism. Khristianskoye chteniye. № 2 (37), 54-138 [in Russian].

2. Berdennikova, E. M. (2008). Homiletic traditions of the spiritual cantatas of I. S. Bach. Kiev: Muzychna Ukrayina [in Ukrainian].

Russian].

3. Veber, M. (2006). Favorites: Protestant Ethics and the Spirit of Capitalism. Moscow: ROSSPEN [in

4. Volzhin, S.V. (2017). Theology of the cross (theologia crucis) by Martin Luther and the story of salvation. Reformatsiya i protestantizm v mirovoy istorii. K 500-letiyu Reformatsii Martina Lyutera: sbornik tezisov i dokladov. St. Petersburg: Sankt-Peterburgskoye Obshchestvo Martina Lyutera [in Russian].

5. Dobiash-Rozhdestvenskaya, O. A. (1917). Cult of sv. Michael in the Latin Middle Ages. V - XIII century. Petrograd: Ekonomicheskaya Tipo-Litografiya [in Russian].

6. Dombrauskene, G. N. (2012). Axiological nature and specificity of the religious symbolism of the German Protestant choral. Vestnik MGUKI. 4 (48), 235-240 [in Russian].

7. Dombrauskene, G. N. (2014). Metatext of the Protestant Chorale: A Semiotic Continuum in the Musical Culture of the West and the East. Extended abstract of doctor's thesis. Saratov: Saratovskiy Morskoy gosudarstvennyy universitet imeni admirala G. I. Nevel'skogo [in Russian].

8. Dombrauskene, G. N. (2013). Semantic syncretism of the anthem «Allein Gott in der Höh'sei Ehr» («Song of the Angels») and the principle of decorating the initial by means of a musical language. Problemy muzykal'noy nauki. 2 (13), 241-245 [in Russian].

9. Kazaryan, G. (2012). Semantic productivity of iconic symbols in musical contexts (I. S. Bach, D. D. Shostakovich). Kritika i semiotika. 16, 106-117 [in Russian].

10. Kolpakova, G. S. (2010). The art of Byzantium. Early and middle periods. St. Petersburg: Izdatel'skaya Gruppa «Azbuka-klassika» [in Russian]. Voronov/

11. Liveriy (Voronov), protoierey (2018). Dogmatic theology. Retrieved from https://azbuka.ru/otechnik/LiverijRussian].

12. Mak-Kim, Donal'd K. (2004). Westminster Theological Terms Dictionary. Moscow: Respublika [in

13. Protoiyerey, G. Florovskiy (2001). Ethos of the Orthodox Church. Pravoslaviye: pro et contra. St. Petersburg: Izdatel'stvo Russkogo Khristianskogo gumanitarnogo universiteta [in Russian].

14. Rudik, Ye. A. (2018). Spiritual cantatas of J. S Bach in the context of Lutheran worship. Candidate's thesis. Saratov: Saratovskaya gosudarstvennaya konservatoriya im. L. V. Sobinova [in Russian].

15. Sannikov, S. (2017). 5 Sola Reformation. Theological principles of heterogeneous Protestantism. Skhid. 3 (149), 83-92 [in Ukrainian].

16. Glory of God (2018). Retrieved from https://azbuka.ru/slava-bozhiya

17. Praise (2018). Retrieved from http://yakov.works/spravki/4_faith_ukaz/22_h_vera/hvala.htm

18. Shveytser, A. (1965). Johann Sebastian Bach. Moscow: Muzyka [in Russian]. German].

19. Evangelisches Kirchengesangbuch. Ausgabe fur die Vereinigte protestanisch Christlishe Kirche der Pfalz [in 